\title{
THE SECOND BISHOP OF THE ARCTIC
}

[Summarized from information in the Canadian Geographical Journal, Vol. 41, No: 1, 1950, p. v.; Beaver. A Magazine of the North, Outfit 281, September 1950, p. 49; and Arctic Circular, Vol. 2, No. 7, 1949, p. 88-89; Vol. 3, No. 3, 1950, p. 35.]

Following the retirement in September 1949 of the Right Reverend Archibald Fleming after sixteen years as Bishop of the Arctic, the Venerable Archdeacon Donald B. Marsh was elected Anglican Bishop of the Arctic in April 1950. He was consecrated on 30 May at St John's Cathedral, Winnipeg, by the Archbishop of Rupert's Land, assisted by a number of northern bishops, and enthroned on 18 June in All Saints' Pro-Cathedral, Aklavik, by Canon C. Montgomery.

The new Bishop of the Arctic went to Canada in 1922, and has spent more than 20 years in the Canadian Arctic, mainly on the west coast of Hudson Bay from where he moved to Aklavik in 1943. Dr Marsh is well-known as an authority on the Caribou Eskimo.

\section{THE EASTERN ARCTIC PATROL VESSEL C. D. HOWE}

[Summarized from notes in the Arctic Circular, Vol. 1, No. 2, 1948, p. 2-4; Vol. 2, No. 1, 1949, p. 10; No. 6, 1049, p. 66; and from information provided by the Director of Marine Services, Department of Transport.]

The first Canadian Eastern Arctic Patrol was made in 1922, in the governmentowned ship Arctic (formerly the Gauss), which went north each successive summer until 1925. Between 1926 and 1931 the Job Seal Fisheries vessel Beothic was chartered annually for two months by the Canadian Government to visit northern posts. In 1932 the Hudson's Bay Company transported the patrol under contract in the Ungava, and in 1933 the Company's ship Nascopie began the first of her long series of patrols, which ended with her wreck in July 1947.1

In 1946, following a decision of the Hudson's Bay Company to withdraw the Nascopie from service, the Canadian Government decided to build their own ship, specially designed for work in arctic waters. Plans were accordingly prepared by Messrs German and Milne of Montreal, in consultation with government officials and experienced arctic navigators. The keel of the proposed vessel was laid at the Davie Shipbuilding and Repairing Company of Levis, Quebec, in December 1948 and she was launched in September 1949.

Details of the C. D. Howe are: length, $276 \mathrm{ft}$.; beam, $50 \mathrm{ft} . ;$ depth, $26 \mathrm{ft}$.; draught when loaded, $18 \frac{1}{2} \mathrm{ft}$; ; deadweight tonnage at $18 \frac{1}{2} \mathrm{ft}$. draught, 2615 tons; engines, two 2000 h.p. "Skinner Marine Uniflow" oil-fired steam; range, 10,000 nautical miles; speed $13 \frac{1}{2}$ knots; hold capacity, 107,000 cu.ft.; refrigerated cargo capacity, 3050 cu.ft. The hull, consisting of arc-welded steel, is built to withstand heavy ice pressure. The vessel is fitted with radar, echosounder, direction-finding equipment, and gyro compass; a helicopter is also provided. Hospital accommodation is available, and a total complement of eighty-eight can be carried.

1 See Footnote 1, p. 272. 